\title{
Alteration in the Function and Expression of SLC and ABC Transporters in the Neurovascular Unit in Alzheimer's Disease and the Clinical Significance
}

\author{
Yongming Jia ${ }^{1, \#, ~ N a ~ W a n g ~}{ }^{2, \#, ~ Y i n g b o ~ Z h a n g ~}{ }^{3}$, Di Xue ${ }^{1}$, Haoming Lou ${ }^{4, *}$, Xuewei Liu ${ }^{1, *}$ \\ ${ }^{1}$ Department of Neuropharmacology, College of Pharmacy, Qiqihar Medical University, Qiqihar, China \\ ${ }^{2}$ Department of Pathophysiology, Basic Medical Science College, Qiqihar Medical University, Qiqihar, China \\ ${ }^{3}$ College of Pathology, Qiqihar Medical University, Qiqihar, China \\ ${ }^{4}$ Department of Medicinal Chemistry and Chemistry of Chinese Materia Medica, School of Pharmacy, \\ Changchun University of Chinese Medicine, Changchun, China
}

[Received February 19, 2019; Revised March 18, 2019; Accepted May 19, 2019]

\begin{abstract}
The neurovascular unit (NVU) plays an important role in maintaining the function of the central nervous system (CNS). Emerging evidence has indicated that the NVU changes function and molecules at the early stage of Alzheimer's disease (AD), which initiates multiple pathways of neurodegeneration. Cell types in the NVU have become attractive targets in the interventional treatment of AD. The NVU transportation system contains a variety of proteins involved in compound transport and neurotransmission. Brain transporters can be classified as members of the solute carrier (SLC) and ATP-binding cassette (ABC) families in the NVU. Moreover, the transporters can regulate both endogenous toxins, including amyloid-beta (Aß) and xenobiotic homeostasis, in the brains of AD patients. Genome-wide association studies (GWAS) have identified some transporter gene variants as susceptibility loci for late-onset $\mathrm{AD}$. Therefore, the present study summarizes changes in blood-brain barrier (BBB) permeability in AD, identifies the location of SLC and ABC transporters in the brain and focuses on major SLC and ABC transporters that contribute to AD pathology.
\end{abstract}

Key words: blood-brain barrier, ATP-binding cassette transporters, solute carrier, Alzheimer's disease

\section{Introduction}

Central nervous system (CNS) barriers are vital to the brain microenvironment for the regulation of neuronal functions, including nutrient transport and protection of the brain from toxins [1]. Brain barriers include the bloodbrain barrier (BBB) and blood-cerebrospinal fluid (CSF) barrier (BCSFB) [2]. BBB, a semipermeable border, is composed of brain microvascular endothelial cells that are sheathed by pericytes, perivascular astrocytic end-feet, neurons and microglia, which constitute a functional unit, namely, the neurovascular unit (NVU). The BCSFB, a fluid-brain barrier, is composed of choroid plexus epithelial cells whose primary function is to secrete CSF; these cells are interconnected by unique apical tight junctions (TJs) [3]. Previous studies found that transporters expressed in endothelial cells could be involved in the influx of essential nutrients such as amino acids and glucose and in the efflux of endogenous toxins such as amyloid-beta (A $\beta)$ and exogenous substance [4].

*Correspondence should be addressed to: Dr. Xuewei Liu, College of Pharmacy, Qiqihar Medical University, Qiqihar, China. Email: lxw_qmu@126.com; Dr. Haoming Luo, School of Pharmacy, Changchun University of Chinese Medicine, Changchun, China. Email: luo.haoming@163.com. \#These authors contributed equally to this work.

Copyright: () 2019 Jia Y et al. This is an open-access article distributed under the terms of the Creative Commons Attribution License, which permits unrestricted use, distribution, and reproduction in any medium, provided the original author and source are credited. 
Brain transporters in the BBB can be classified as uptake transporters (including the solute carrier (SLC) superfamily) and efflux transporters (including the ATPbinding cassette (ABC) superfamily). These transporters are considered to play key roles in the treatment and pathogenesis of CNS disorders such as AD (Fig. 1) [5, 6]. SLC transporters in the brain, including SLCO, SLC22A, $S L C 28 A$ and SLC29A, can transport substrates from blood to the brain to meet the high energy and nutrient demands of the brain; such substrates include organic cations and anions, peptides, steroids and drug conjugates [7]. However, as a cellular defense system, ABC transporters extrude metabolic wastes from the cytoplasm to the blood and prevent most xenobiotics from entering the brain.
$\mathrm{ABC}$ transporters, classified into seven subfamilies from $A B C A$ to $A B C G$, show extensive overlaps in substrate specificity [8]. At the same time, $A B C$ transporters are expressed widely in endothelial cells, neurons and glial cells of the brain. Emerging evidence suggests that abnormal NVU transporter expression is correlated with CNS diseases, including glioblastoma, Parkinson's disease and $\mathrm{AD}[9,10]$. Furthermore, loss of BBB integrity and transporter dysfunction affect the entry or efflux of compounds, disrupting CNS homeostasis and thereby exacerbating CNS diseases, including AD and stroke.

\section{Blood}

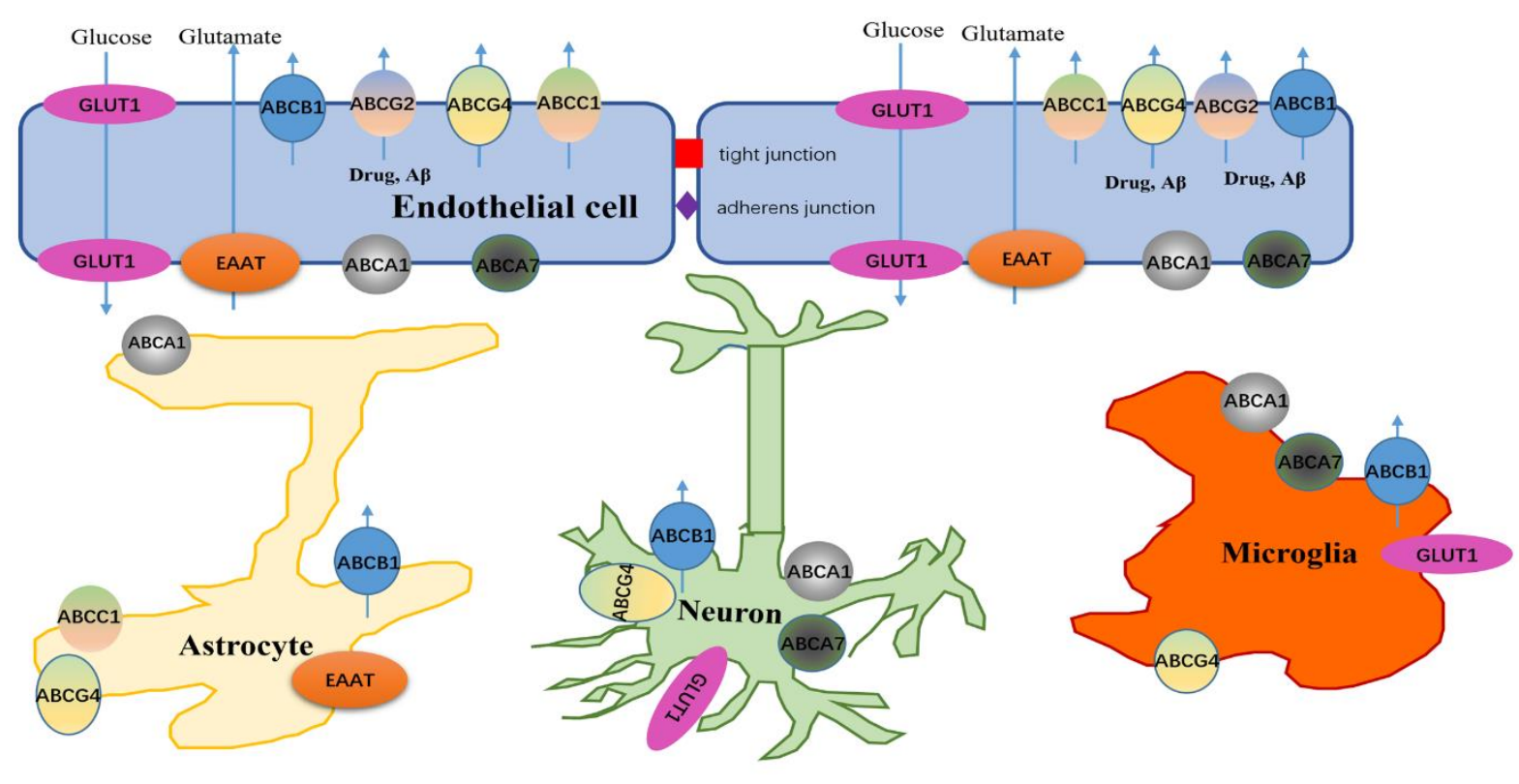

Brain

Figure 1. SLC and ABC transporters in the NVU.

$\mathrm{AD}$, a typical neurodegenerative disorder, is characterized by the presence of amyloid plaques and neurofibrillary tangles. It is also associated with microvascular dysfunction and/or degeneration in the brain [11]. It is well known that microvessels are key sites for the exchange of substances, such as nutrients, energy substrates and the brain's supply of oxygen, between the brain and circulating blood [12]. Microvascular pathology causes the disruption of BBB integrity. Furthermore, studies have reported that the $\mathrm{BBB}$ is significantly affected in different models of AD-related microvascular pathology [13]. Moreover, destruction of BBB integrity diminishes the clearance of neurotoxic molecules such as soluble $A \beta$ from the CNS and consequently leads to accumulated $A \beta$ in the brain [14]. Some transporters, especially $\mathrm{ABC}$ transporters, can mediate $\mathrm{A} \beta$ homeostasis in the brain and are key players in AD pathology [15]. This review summarizes changes in BBB permeability in $\mathrm{AD}$, identifies the location of SLC and $\mathrm{ABC}$ transporters in the brain and focuses on major SLC and $A B C$ transporters that contribute to $\mathrm{AD}$ pathology. 


\section{BBB breakdown in AD}

BBB permeability can be influenced by physicochemical factors, including the molecular weight, lipid solubility and surface area of molecules. In general, most smallmolecule drugs cannot pass through the BBB. Only certain small molecules that are lipid soluble with less than a 400 Da molecular weight can pass through BBB. In addition, physiological factors that influence $\mathrm{BBB}$ permeability include efflux transporters such as $\mathrm{ABCB} 1$, plasma protein binding, cerebral blood flow and an enzymatic surveillance system [16, 17].

$\mathrm{BBB}$ permeability was found to change in patients with mild cognitive impairment (MCI) and AD by using an advanced dynamic contrast enhanced (DCE)-MRI method [18]. Nevertheless, the cause and progression of $\mathrm{BBB}$ breakdown and dysfunction in $\mathrm{AD}$ are still not fully known. Numerous transgenic AD models have been used to explore the mechanism of BBB breakdown. For instance, studies have shown that $\mathrm{APP}^{\mathrm{Sw} / 0}$ mice, which overexpress cellular APP and exhibit $A \beta$ overproduction, finally develop BBB breakdown. BBB breakdown can be demonstrated by capillary leakages of blood-derived molecules, including albumin and IgG, loss of endothelial tight junction proteins and endothelial cell and pericyte degeneration in AD [19]. Similarly, in presenilin1 (PSEN1) and Tau transgenic models, BBB leakage of Evans blue, perivascular deposits and major cerebrovascular pathology indicates BBB breakdown. The strongest genetic risk factor for $\mathrm{AD}$ is the $\mathrm{E} 4$ variant of apolipoprotein $\mathrm{E}$ (ApoE), which can affect $A \beta$ clearance and tau-related neurodegeneration [20]. Furthermore, in Apoe $^{-/}$mice, BBB breakdown is presented by loss of TJs, loss of perivascular pericytes, and hemosiderin deposits [21]. Aberrant expression of brain transporters can also be seen in transgenic models $[22,23]$. In in vitro $B B B$ models, $A \beta$ oligomers induce the disruption of tight junction scaffold proteins via the receptor of advanced glycation end-products (RAGE)mediated autophagy pathway in capillary endothelial cells of the murine brain (bEnd.3), leading to BBB breakdown [24].

\subsection{BBB junctional molecules in $A D$}

TJs and adherent junctions (AJs) between BBB endothelial cells are a highly specialized structure with barrier integrity that can limit paracellular permeability and thus maintain brain homeostasis [25]. Molecular components of TJs contain membrane proteins, such as claudins and occludin, and cytoplasmic proteins, such as zonula occludens-1 (ZO-1), which are involved in the construction of TJs at the BBB [26]. Similarly, the AJ also plays a key role in endothelial permeability. The major proteins of AJs are VE-cadherin, catenin and platelet endothelial cell adhesion molecule (PECAM) [27]. The AJ proteins directly regulate the paracellular route and alter transcellular exchange and affect certain enzymes and transporters in the BBB [25]. Recent studies have shown that BBB breakdown in the hippocampus can be found in $\mathrm{AD}$ patients at the early stage [18]. Consistent with these findings, in 20 independent postmortem tissues from $\mathrm{AD}$ patients, $\mathrm{BBB}$ breakdown was observed, accompanied by brain capillary leakages and loss of BBB tight junctions [28]. Changes in junctional protein expression influence a variety of protein functions. Under normal conditions, claudin-5 and ZO-2 display a continuous distribution along the plasma membrane in cell-cell contacts, but brain endothelial cells treated with $\mathrm{A} \beta_{1-42}$ for 3 days cause $\mathrm{TJ}$ protein relocation to the cytoplasm, decreased occludin expression and altered $\mathrm{BBB}$ integrity, contributing to the pathogenesis of $\mathrm{AD}$ [29]. However, changes of TJs have impaired BBB against small molecules $(<800$ Da) but not larger molecules. Chemicals such as TJ modulators are used for drug delivery to neuronal regions [22, 30-31]. This suggests to us a new way to deliver potential drugs across the $\mathrm{BBB}$ into the $\mathrm{CNS}$ to treat neurodegenerative diseases.

\subsection{Pericyte degeneration in $A D$}

Pericytes are a major component of the NVU. As BBB gatekeepers, they transport nutrients and waste molecules between the blood and the brain interstitial fluid [13, 32] and help to regulate blood flow. Mounting evidence has shown that pericytes are related to BBB pathology in $\mathrm{AD}$. Pericyte degeneration and loss have been found in $\mathrm{AD}$ patients by postmortem analysis [33, 34]. Moreover, $\mathrm{A} \beta$ deposition around brain capillaries can promote ROS overproduction in pericytes and induce toxicity in pericytes, leading to $\mathrm{BBB}$ breakdown $[35,36]$. Progressive BBB breakdown is displayed in pericytedeficient mice, leading to hippocampal neuron loss and behavioral deficits [37]. Interestingly, pericytes are involved in $A \beta$ clearance in the brain [38]. Pericytes clear $\mathrm{A} \beta$ aggregates via an LRP1-dependent apoE isoformspecific mechanism in $A P P^{\mathrm{Swe} / 0}$ mice [39]. In addition, mesenchymal stem cell-derived pericyte implantations have the capacity to reduce $\mathrm{A} \beta$ deposition in the hippocampus of APP transgenic mice and related pathology [32]. These studies suggest that pericytes may be a potential therapeutic target for controlling $A \beta$ clearance in $\mathrm{AD}$.

\section{SLC transporters and AD}

\subsection{Glutamate transporters}


Glutamate transporters, members of the SLC1 and SLC17 family, comprise two subclasses, namely, the excitatory amino acid transporter (EAAT) family and vesicular glutamate transporter (VGLUT) family, regulating glutamate homeostasis at the synapse and affecting excitotoxic neuronal damage in certain neurodegenerative diseases such as AD [40]. EAAT1 (SLC1A3) and EAAT2 (SLC1A2) are expressed in astrocytes and are responsible for $5 \%$ and $90 \%$ of the glutamate transport in the CNS, respectively $[41,42]$. Studies have shown that pathologyspecific EAAT2 splice variants in the brains of $\mathrm{AD}$ patients obtained by autopsy and glutamatergic dysfunction are involved in the pathophysiology of $\mathrm{AD}$ and occur in the early stage of AD [43]. The accumulation of excessive extracellular glutamate has been considered a risk factor in neurodegenerative diseases [44]. In addition, memantine, as a typical metabotropic glutamate receptor antagonist, is used in the symptomatic treatment of AD. Therefore, EAATs might be an intriguing therapeutic target [44]. However, there are conflicting reports of EAAT2 expression in different animals with AD. In transgenic mice overexpressing mutant human APP, the expression and activity of EAAT1 and EAAT2 protein were found to be decreased in the mouse brain [45]. Similarly, in APP transgenic mice, the researcher found that EAAT2 protein expression decreased in the cortex and hippocampus, leading to a drastic glutamate reuptake activity decrease [46]. However, in double (APP/PS1) and/or triple transgenic (3xTg-AD) mice, EAAT2 protein expression did not change over the lifetime of the mice [47]. These conflicting results may be related to the EAAT2 location and methods of qualitative analysis, and further research is needed to verify the findings. Because of glutamate homeostasis in $\mathrm{AD}$, researchers have focused on developing or screening new compounds that can activate EAAT protein expression, providing a beneficial effect in AD patients.

\subsection{Glucose transporter}

Glucose transporters (GLUTs) can be divided into two major families, namely, the SLC2A family (GLUTs) and SLC5A family (SGLTs) [48]. The two families have 14 isoforms (GLUTs1-14) and 12 isoforms (SGLTs 1-12). Endothelial cells at the BBB can transport glucose rapidly to support the glucose requirements of the brain [49]. GLUTs are cell type-specific and are affected by disease conditions. GLUT1 is predominantly expressed at both the luminal and abluminal membranes in the endothelium of the BBB [50]. Glucose in the extracellular space is permeated into astrocytes, microglia and neurons through different GLUTs [51]. GLUT1 and GLUT3 expressed in neurons are major glucose transporters in the regulation of glucose homeostasis in the brain [52]. The majority of brain glucose is used in the formation of ATP energy to maintain cognitive functions [53]. Glucose metabolism abnormalities play a crucial role in the pathogenesis of $\mathrm{AD}$ [54].

In sporadic AD, ATP produced by glucose metabolism in the brain declines by 50\% [55]. Recent research has found both altered glucose metabolism in the brain and reduced glucose transporter expression associated with $\mathrm{AD}[56,57]$. Evidence has shown that glucose transport is reduced in AD patients' brain regions, such as the cortex, hippocampus, and cerebral microvessels [58]. Furthermore, GLUT1 and GLUT3 protein concentrations in the cerebral cortex are reduced significantly in AD patients [59]. Moreover, GLUT1 deficiency leads to early BBB breakdown in Slc2al ${ }^{+/-}$ mice, and decreased GLUT1 protein expression is found in the brain microvessels of patients with $\mathrm{AD}$ and cognitive impairment $[60,61]$. In $S l c 2 a 1^{+-}$transgenic mice, rapid BBB breakdown can be seen following secondary neurodegeneration caused by acceleration of $A \beta$, suggesting that GLUT1 plays a critical role in AD [60]. Moreover, GLUT1 deficiency in the endothelium of mice with overexpressed APP exacerbates cerebral microvascular degeneration and BBB breakdown, leading to accumulated $A \beta$ and behavioral deficits [60]. Indeed, reduced GLUT1 at the BBB has been reported to be one of the earliest features of $\mathrm{AD}$ pathophysiological events and symptoms [62]. As a consequence, a number of studies suggest that impaired glucose metabolism and decreased glucose transporter expression are causative factors in the progression of $\mathrm{AD}$. However, the therapeutic potential of targeting glucose transporters has not been defined and requires further research. GLUT1 could be a molecular marker for the onset of $\mathrm{AD}$ and a therapeutic target for preventing, delaying or treating $\mathrm{AD}$.

\subsection{Nucleoside transporters}

Nucleoside transporters can be classified into two families: the SLC28A family (concentrative nucleoside transporters, CNTs) and the SLC29A family (equilibrative nucleoside transporters, ENTs) [63]. The two SLC families have 3 isoforms (CNTs1-3) and 4 isoforms (ENTs 1-4). CNTs are primarily expressed in epithelial tissues, such as the kidney and liver. CNT2 and CNT3 genes are highly expressed in human brain regions, such as the hippocampus and medulla oblongata. Moreover, CNT2 has been detected in rat brain endothelial cells [64]. However, CNTs1-3 expression levels are below the limit of quantification in proteomic analyses of humans, indicating that these proteins may not be involved in the transport of nucleosides in humans [65]. 
ENT proteins show a wide tissue distribution in the liver, kidney, intestine and brain. They are highly expressed in the plasma membrane and the frontal and parietal cortices [66]. ENT1 is the main regulator of homeostatic maintenance of adenosine levels depending on the concentration gradient of the membrane. Recent studies have found that $\mathrm{J} 4$, a small adenosine analogue, can inhibit ENT1 function and further prevent the decline in spatial memory in APP/PS1 mice. Furthermore, the author demonstrated that chronic treatment with J4 improves impaired basal synaptic transmission and abnormal neuronal plasticity-related signaling pathways [67]. ENTs could mediate the transport of several nucleoside drugs into the brain. These results suggest that ENT1 is a therapeutic option in AD treatment.

\subsection{Other uptake transporters and $A D$}

L-alpha amino acid transporters (LATs), members of SLC7 and SLC43, comprise four isoforms: SLC7A5 (LAT1), SLC7A8 (LAT2), SLC43A1 (LAT3), and SLC43A2 (LAT4), regulating large and small amino acid homeostasis in the brain [68]. LAT1 and LAT2 are expressed on luminal and abluminal surfaces of the BBB, and LAT1 can transport several CNS-active drugs, such as gabapentin, pregabalin, L-DOPA, and methyldopa [6870]. However, LAT1 mRNA and protein levels in astrocytes of $\mathrm{AD}$ transgenic primary mice are not changed compared with those of wild-type mice. In addition, LAT1 function at the BBB in APP/PS1 transgenic mice is also unchanged compared with that in nontreated wild-type mice [71].

Organic anion transporting polypeptides (OATPs) are SLCO transporters with 11 isoforms identified in humans. OATP transporters are widely expressed in many tissues, such as the liver, kidney, placenta, and brain [72]. OATP1A2 (Oatp1a4/Slco1a4 in mice) and OATP1C1 have been found at the BBB [73]. Moreover, OATP1A2 plays a key role in drug delivery to the brain and can mediate the uptake of drugs such as digoxin and DPDPE in the BBB [74]. Recent studies have found that rosuvastatin and taurocholate, which are inhibitors of Oatp1a4, decrease the $A \beta$ concentration in mouse brains using in situ brain perfusion and have further investigated the interaction between Oatpla4 and $A \beta$ by coimmunoprecipitation, indicating that Oatpla4 at least partly mediates A $\beta$ uptake [75]. Whether OATP1A2 and/or Oatp1a4 expression levels are changed or whether pathological stressors can change OATP expression in the $\mathrm{BBB}$ requires further research.

Organic anion transporters (OATs) and organic cation transporters (OCTs) belong to the SLC22 family and are expressed in many tissues, including the small intestine, kidney, liver, placenta, and brain capillaries.
Under normal conditions, OAT expression shows distinct differences at the BBB, and OAT1 and OAT3 expression are below the limit of quantification in human brain microvessel endothelial cells and astrocytes [65, 76]. However, in an OAT1-deficient AD mouse model, learning- and memory-related behavior deficiency, reduced LTP levels and higher soluble $A \beta$ concentrations in the early stage were increased compared with the corresponding levels in control tg2576 mice, suggesting that OAT1 may affect the AD process [77]. In addition, Oat 3 and Oct 2 protein expression levels were increased 1.3- and 1.4-fold, respectively, in the kidneys of APP/PS1 transgenic mice compared with those in wild-type mice, which may have affected drug elimination in this $\mathrm{AD}$ model [78].

OCT1 and OCT2 are mainly expressed on the luminal surface of brain capillary endothelial cells isolated from the brain cortex of humans, as analyzed by using confocal microscopy, suggesting that these two isoforms mediate the uptake of substrates across the BBB into the brain [79]. Unfortunately, to date, no further research has focused on whether OCT expression at the BBB changes.

\section{ABC transporters and AD}

\section{1. $A B C B 1$}

$\mathrm{ABCB} 1$, also known as P-gp, is widely expressed in barrier and excretory tissues, providing effective protection against harmful nonpolar therapeutic drugs and xenobiotics. It was first detected at vascular endothelial surfaces of the human BBB in 1989 [80]. It is clear that $\mathrm{ABCB} 1$ is also expressed in pericytes, astrocytes, the choroid plexus and neurons [81]. ABCB1 of the BBB plays a central role in the occurrence and development of $\mathrm{AD}$ [82]. Various studies have shown that ABCB1 expressed by the BBB can regulate the transport of endoxenobiotics through the encephalon [83]. In 2001, it was first reported that $A \beta$ interacts with $A B C B 1$, by using ABCB1-overexpressing HEK293 cells, which provided strong evidence that $\mathrm{ABCB} 1$ is an $\mathrm{A} \beta$ transporter [84]. Furthermore, a clinical discovery provided evidence that ABCB1 function, which can be assessed using (R)-[ $\left[{ }^{11} \mathrm{C}\right]$ verapamil and positron emission tomography (PET) in vivo, was decreased in $\mathrm{AD}$ patients compared with agematched healthy controls [85]. Similarly, in an in vivo study, ABCB1 deficiency at the BBB led to $\mathrm{A} \beta$ deposition in a P-gp deficient null mouse model. Furthermore, compared with P-gp wild-type mice, the levels of brain $A \beta$ and enhanced $A \beta$ deposition were increased in P-gpdeficient null mice, establishing a direct link between Pgp and $\mathrm{A} \beta$ metabolism in vivo [86]. Moreover, compared with $\mathrm{APP} / \mathrm{PS}^{+/-} \mathrm{P}$-gp ko mice, a significant reduction of 
$\mathrm{A} \beta$ levels was found in $\mathrm{APP} / \mathrm{PS}^{+/} \mathrm{P}$-gp $w t$ mice, suggesting that upregulating $\mathrm{P}$-gp might be a valid approach to reduce $A \beta$ levels in the brain [87]. In 243 nondemented human brain tissues, $A \beta$ deposition in the vessel walls was found in blood vessels with low ABCB1 protein expression using an immunohistochemical method in the medial temporal lobe, while those with high $A B C B 1$ protein expression showed low deposition of $A \beta$, suggesting that P-gp may influence the elimination of $A \beta$ from the brain [88]. Conversely, when porcine brain microvascular endothelial cells (PBECs) were treated with $\mathrm{A} \beta_{42}$ for $48 \mathrm{~h}, \beta \mathrm{ABCB} 1$ protein expression and $A B C B 1$ activity were reduced significantly [89]. Additionally, studies have demonstrated that ABCB1 protein levels at the $\mathrm{BBB}$ decline during normal aging, which is positively correlated with the accumulation of $\mathrm{A} \beta$ in $\mathrm{AD}$ [90]. Pro-inflammatory cytokines, including TNF- $\alpha$, IL- $1 \beta$, and IFN- $\gamma$, have been found in models of $\mathrm{AD}$ induced by $\mathrm{A} \beta$, and these cytokines can downregulate ABCB1 mRNA and protein levels, interrupting the negative feedback loop between $A \beta$ and ABCB1 [91]. It demonstrated that oxidative stress (OS) can increase $\mathrm{ABCB} 1$ expression and activity at the BBB endothelium in primary cultured rat brain endothelial cells [92]. However, conflicting data exist regarding the contribution of $\mathrm{ABCB} 1$ to the clearance of $\mathrm{A} \beta$. For instance, in MDCK cells stably transfected with $\mathrm{ABCB} 1$ transported little transcytosed radiolabeled $\left[{ }^{125} \mathrm{I}\right] \mathrm{A} \beta$ from the basolateral to the apical compartment, and the $A \beta$ clearance quotient showed no significant difference in MDCK-P-gp and MDCK-Parental monolayers, suggesting that increased $\mathrm{ABCB} 1$ expression is sufficient to promote $\mathrm{A} \beta$ transcytosis [93]. Similarly, when rats were pretreated with $A B C B 1$ inhibitors (quinidine and/or verapamil), the amount of $A \beta$ crossing the BBB in rats was not changed [94]. Collectively, the paradoxical results can be explained by using different cell lines in the above studies and animal models, showing that some physiological changes may affect the accumulation of $A \beta$.

Researchers have found a new therapeutic treatment or drug targeting $\mathrm{ABCB} 1$ to treat $\mathrm{AD}$. In vivo studies have shown that ibuprofen treatment can restore decreased ABCB 1 mRNA and protein expression in APP/PS1 mice [95]. The study found that Huperzine A (HupA) is a substrate of P-gp. HupA extracted from Huperzia serrata is a potent inhibitor of acetylcholinesterase (AChE). HupA has been used in the treatment of AD by targeting central nicotinic and muscarinic receptors and exerts neuroprotective properties by producing a potent antiinflammatory response [96]. In Abcb1-deficient mice, the brain-to-plasma concentration ratio of Huperzine A was significantly increased. The results further suggested that P-gp can mediate Huperzine A distribution in the brain distribution [97]. Similarly, 1,1'-([1,1'-biphenyl]-4,4'- diyl)bis(3-(piperidin-1-yl)propan-1-one)dihydrochloride (DL0410), a novel synthetic dual AChE/ butyrylcholinesterase (BuChE) inhibitor for $\mathrm{AD}$ treatment, showed multitarget properties for $\mathrm{AD}$ treatment, such as improving cognitive deficits, enhancing synapse loss, inhibiting the activity of cholinesterase and reversing the plaque load caused by $\mathrm{A} \beta$ [98-100]. P-gp mediated DL0410 transport in Caco-2 and MDCK-MDR1 cells, suggesting that further efficacy and safety should be considered in drug-drug interactions in AD treatment [101].

\section{2. $A B C G 2$}

$\mathrm{ABCG} 2$, known as breast cancer resistance protein (BCRP), is highly expressed in BBB endothelial cells and plays protective roles in blocking the absorption of xenobiotics [102]. Mounting evidence has shown that ABCG2 mediates A $\beta$ transport in brain endothelial cells. In vitro studies showed that $\mathrm{ABCG} 2$ can mediate the cellular efflux of $A \beta_{40}$ in HEK293 cells stably transfected with human ABCG2. In addition, the study further found that $\mathrm{A} \beta$ uptake in $A b c b 1$-deficient mice can be blocked by GF120918 (a dual inhibitor of Abcb1 and Abcg2) by using an in situ brain perfusion technique, suggesting that Abcg2 expressed in BBB is involved in the transport of $\mathrm{A} \beta_{40}$ [103]. Furthermore, in $A B C G 2$-deficient mice, $\mathrm{A} \beta$ deposition increased significantly compared with that in wild-type mice after intravenous injection of $A \beta$, suggesting that $A B C G 2$ can prevent $A \beta$ from entering the brain [104]. In contrast with $A B C B 1$ levels, $A B C G 2$ gene and protein levels were upregulated in the cerebral vessels of $\mathrm{AD}$ patients and in the brains of mouse $\mathrm{AD}$ models [105]. The authors suggested that ABCG2 upregulation might act as a biomarker of cerebral amyloid angiopathy (CAA) vascular pathology. In addition, a genome-wide association study revealed the effect of $\mathrm{ABCG} 2 \mathrm{C} / \mathrm{C}$ genotype absence or presence with apoE (APOE) on the risk of developing $\mathrm{AD}$, which is a possible predisposing genetic factor for late-onset AD [106]. Some compounds that inhibit $\mathrm{A} \beta$ aggregation in $\mathrm{AD}$ models can penetrate the brain endothelium, mediated by ABCG2 [107].

\section{3. $A B C G 4$}

ABCG4 is a half-transporter that always dimerizes with ABCG1 in order to become functional [108]. ABCG4 is expressed in brain capillary endothelial cells, glial cells and neurons and mediates the efflux of cholesterol to form apoE-containing lipoprotein $[109,110]$. To the best of our knowledge, several studies have found that ABCG4 can affect $A \beta$ production and $A \beta$ clearance. Sano et al. reported that mature APP levels were increased in HEK/APPsw cells transiently transfected with ABCG4 
compared with ABCG4-KM, which is a Walker A lysine mutant of ABCG4. Furthermore, the author demonstrated that the altered distribution of $\gamma$-secretase caused the reduced secretion of $A \beta$. They also demonstrated that when ABCG1 and ABCG4 were suppressed in SH-SY5Y cells, $A \beta$ secretion was increased. These authors reasoned that $A B C G 4$ could suppress $A \beta$ production and $A \beta$ plaque formation $\beta[111]$. Studies have reported the effect of ABCG4 on the clearance of $A \beta$ from BBB. ABCG4 mediates the cellular efflux of $A \beta$ in HEK293 cells stably transfected with mouse abcg4. Moreover, probucol inhibits $A \beta$ efflux from HEK293-abcg4 cells completely [103]. Similarly, using an Abcg4-deficient mouse model, the author demonstrated that abcg4 functions at the luminal surface of mouse brain capillary endothelial cells and can transport both $A \beta$ and desmosterol. The author linked disordered sterol metabolism to competitive inhibition of $\mathrm{A} \beta$ efflux and progression of $\mathrm{AD}$ [110]. Furthermore, the study showed that ABCG4 levels are significantly upregulated in microglial cells and might contribute to $A \beta$ degradation through phagocytosis [112]. Further studies are necessary to confirm the ABCG4 function in $\mathrm{AD}$ pathology and that ABCG4 may increase the clearance rate of $A \beta$ for the prevention of $A D$.

\section{4. $A B C A 1$}

ABCA1, also called cholesterol efflux regulatory protein (CERP), is widely expressed in brain tissues and can stimulate the efflux of cholesterol and phospholipid to ApoE [113]. Defects in cholesterol metabolism in the brain have been shown to be an important risk factor in $\mathrm{AD}$ pathogenesis because cholesterol levels are synergistic with $A \beta$ production by affecting BACE1 [114]. ABCA1 is also expressed in brain capillary endothelial cells and neurons, but it does not transport $A \beta$ directly [115]. ABCA1 can affect $A \beta$ production and degradation rather than efflux transport across the BBB. The study showed that increased ABCA1 gene and protein levels induced by LXR ligands could increase secreted $A \beta$ concentration and could be reversed by blocking ABCA1 expression using the RNAi method [116]. Furthermore, ABCA1 and ABCG1 regulates cholesterol homeostasis in $\mathrm{BBB}$ models in vitro. Bexarotene (an RXR agonist) induces ABCA1 expression, promotes cholesterol exchange between the blood and brain and decreases the influx of $A \beta$ across the BBB [117]. Additionally, recent research found that high glucose downregulates ABCA1 expression and increases intracellular cholesterol levels, which regulates LXR $\alpha /$ ABCA1-mediated localization in the lipid raft and stimulates BACE1 in SK-N-MC cells [118]. These results suggest that ABCA1 is involved in the role of cholesterol and lipid rafts on APP processing by BACE1.
ABCA1 regulates levels of ApoE and ApoE lipidation, while $A p o E$ is regarded as a chaperone for $A \beta$, affecting its clearance and aggregate [119]. In 12-monthold PDAPP Abca1 ${ }^{-/-}$mice, the A $\beta$ level was found to be markedly higher than that in PDAPP $\mathrm{Abca}^{-/-}$mice without affecting APP processing, and carbonateinsoluble ApoE co-localized with $A \beta$ plaques, implying that poorly lipidated ApoE co-deposits with insoluble $A \beta$ [120]. The author further found that overexpression of Abcal in the mouse brain increases ApoE lipidation and decreases A $\beta$ deposition [121]. Similarly, ABCA1 reduction caused by microRNA-33 overexpression increases cellular cholesterol and Thioflavin S-positive plaques, leading to amyloidogenesis in mice [122]. However, in the hippocampal region of $\mathrm{AD}$ patients, ABCA1 mRNA expression is positively correlated with the severity of dementia [123]. Thus, affecting ABCA1 expression and its activity can be considered a therapeutic target to influence apoE/A $\beta$ interactions in the brain. A recent study found that CS-6253, which can activate ABCA1 directly (ABCA1 agonist) in vitro, increased the lipidation of apoE4 and reversed apoE4-driven $A \beta$ accumulation and tau hyperphosphorylation [113].

Some environmental and genetic factors could be the cause of late-onset AD. Dichlorodiphenyltrichloroethane (DDT) impairs the function of ABCA1 and further increases $A \beta$ levels in H4-A $\beta$ PPswe cells [124]. ABCA1 $\mathrm{N} 1800 \mathrm{H}$, a functional mutation found in $0.2 \%$ of individuals, was associated with a high risk of $\mathrm{AD}$ in the general population [125]. Furthermore, the ABCA1 rs2422493 (C-477T) polymorphism is statistically significantly associated with increasing AD risk in three genetic models [126]. In Han Chinese patients with AD, the ABCA1 rs2230806 polymorphism responded better to donepezil (DNP) treatment, which is a medication used to improve the cognition of patients with AD [127]. Similarly, the ABCA1 R219K K allele is a risk factor for lower ABCA1 in AD patients in northern China [128]. Based on the above results, the small molecular inducer P2X7 was found to enhance ABCA1 and ApoE without direct activation of the LXR pathway [129].

\section{5. $A B C A 7$}

ABCA7, another CERP, shares 54\% sequence identity with $\mathrm{ABCA} 1$ and is expressed in microglia, neurons, and brain endothelial cells $[130,131]$. ABCA7 mediates the transfer of phospholipids and cholesterol across cell membranes to lipid-poor apolipoprotein acceptors [132]. Several groups have demonstrated that ABCA7 may regulate $A \beta$ homeostasis and $A \beta$ pathology. Studies have shown that ABCA7 plays a role in APP processing, leading to enhanced $A \beta$ secretion, which may be linked to endocytosis activity in microglia [133]. In Chinese 
hamster ovary (CHO) cells stably expressing APP, ABCA7 could also significantly inhibit $A \beta$ secretion without affecting the activities of $\alpha$ - and $\beta$-secretases [132]. In APP/PS1 mice, ABCA7 deficiency increases A $\beta$ levels and exacerbates the amyloid plaque burden [134]. Consistent with these results, in transgenic mice, ABCA7 deficiency may aggravate the amyloid plaque burden in the brain [135]. ABCA7 is also involved in $A \beta$ clearance in microglia. In Abca $7^{-/-}$mice, phagocytic $\mathrm{A} \beta$ clearance in microglia was found to be reduced significantly compared with that in wild-type mice [136]. Additionally, absent ABCA7 in mouse endothelial cells causes $A \beta$ peptide reduction from basolateral-to-apical transport [137]. The author showed that $\mathrm{ABCA} 7$ affects $\mathrm{A} \beta$ transport not directly but in the presence of ApoI-J.

Table 1. An overview of the SLC and ABC transporters in the brain, with the proposed relevance to AD pathology.

\begin{tabular}{|c|c|c|c|}
\hline Transporter & Location & Function & References \\
\hline EAAT1/2 & Expressed in astrocytes & $\begin{array}{l}\text { Regulate glutamate homeostasis and affect excitotoxic } \\
\text { neuronal damage in } \mathrm{AD}\end{array}$ & {$[40]$} \\
\hline GLUT1 & $\begin{array}{l}\text { Expressed in endothelial cell, } \\
\text { neurons, astrocytes and } \\
\text { microglia }\end{array}$ & $\begin{array}{l}\text { Regulate glucose homeostasis in the brain } \\
\text { Accelerate BBB breakdown, following secondary } \\
\text { neurodegeneration caused by } \mathrm{A} \beta\end{array}$ & $\begin{array}{l}{[52]} \\
{[60]}\end{array}$ \\
\hline ABCB1 & $\begin{array}{l}\text { Expressed in endothelial cells, } \\
\text { pericytes, astrocytes, the choroid } \\
\text { plexus and neurons }\end{array}$ & $\begin{array}{l}\text { Transport of endoxenobiotics across the encephalon } \\
\text { Involved in the clearance of } A \beta \text { from the brain into blood } \\
A B C B 1 \text { at the BBB declines during normal aging }\end{array}$ & $\begin{array}{l}{[83]} \\
{[85]} \\
{[90]}\end{array}$ \\
\hline ABCG2 & $\begin{array}{l}\text { Highly expressed in BBB } \\
\text { endothelial cells }\end{array}$ & Mediates the cellular efflux of A $\beta$ in HEK293 cells & {$[103]$} \\
\hline ABCG4 & $\begin{array}{l}\text { Expressed in brain capillary } \\
\text { endothelial cells, glial cells and } \\
\text { neurons }\end{array}$ & $\begin{array}{l}\text { Mediates the efflux of cholesterol to form apoE-containing } \\
\text { lipoprotein } \\
\text { Suppresses ABCG1 and ABCG4 function and increases A } \beta \\
\text { secretion } \\
\text { Mediates the cellular efflux of A } \beta \text { in HEK } 293 \text { cells stably } \\
\text { transfected with mouse abcg } 4\end{array}$ & $\begin{array}{l}{[109,110]} \\
{[111]} \\
{[103]}\end{array}$ \\
\hline ABCA1 & $\begin{array}{l}\text { Widely expressed in brain } \\
\text { tissues }\end{array}$ & $\begin{array}{l}\text { Stimulates the efflux of cholesterol and phospholipid to } \\
\text { ApoE } \\
\text { Increased ABCA1 levels induced by LXR ligands can } \\
\text { increase the secreted A } \beta \text { concentration } \\
\text { Decreases the influx of A } \beta \text { across the BBB } \\
\text { Regulates the levels of ApoE and ApoE lipidation } \\
\text { ABCA1 rs } 2422493 \text { (C-477T) polymorphism are associated } \\
\text { with increasing AD risk }\end{array}$ & $\begin{array}{l}{[113]} \\
{[118]} \\
{[117]} \\
{[119]} \\
{[126]}\end{array}$ \\
\hline ABCA7 & $\begin{array}{l}\text { Expressed in microglia, neurons, } \\
\text { and brain endothelial cells }\end{array}$ & $\begin{array}{l}\text { Mediates the transfer of phospholipids and cholesterol } \\
\text { across cell membranes } \\
\text { Inhibits A } \beta \text { secretion without affecting the activities of } \alpha \text { - } \\
\text { and } \beta \text {-secretases } \\
\text { Plays roles in APP processing, leading to enhanced A } \beta \\
\text { secretion } \\
\text { Phagocytic A } \beta \text { clearance in microglia is reduced in Abca } 7^{-/-} \\
\text {mice } \\
\text { ABCA7 SNPs are relate to the occurrence of AD }\end{array}$ & $\begin{array}{l}{[132]} \\
{[132]} \\
{[133]}\end{array}$ \\
\hline ABCC1 & $\begin{array}{l}\text { Localized in brain endothelial } \\
\text { cells, astrocytes and pericytes }\end{array}$ & $\begin{array}{l}\text { Lack of } A B C C 1 \text { could increase } A \beta_{40} \text { and } A \beta_{42} \text { levels } \\
\text { compared to those in } A B C C 1 \text {-positive controls }\end{array}$ & {$[153]$} \\
\hline
\end{tabular}

Data from numerous genome-wide association studies (GWAS) have shown that $A B C A 7$, the only ABC transporter identified by GWAS, is a risk factor for lateonset AD [138, 139]. GWAS have identified some gene variants that are considered to be established $\mathrm{AD}$ risk factors, such as ApoE, apolipoprotein $\mathrm{J}$ (ApoJ, clusterin) and phosphatidylinositol binding clathrin assembly protein $(P I C A L M)[140,141]$. Both ApoE and ApoJ can affect $A \beta$ clearance. Bell et al demonstrated that $A \beta$ clearance in the BBB increased when ApoE bound to $A \beta$ through LRP1-mediated transport, while ApoJ bound to $A \beta$ through LRP2-mediated transport [142, 143]. The 
sequence of the ABCA7 SNP rs3764650 has been implicated in the occurrence of $\mathrm{AD}$ and is associated with a modest reduction in $A B C A 7$ expression [144, 145]. Furthermore, the $A B C A 7$ SNP (rs3764650) is also associated with $\mathrm{AD}$ risk in the Chinese population, while age and ApoE4 status could increase its risk [146]. $A B C A 7$ rs 3764647 and $A B C A 7$ rs 115550680 have been associated with AD risk in African Americans [147, 148]. $A B C A 7$ rs4147929 is associated with LOAD in the Spanish population [149].

\section{6. $\mathrm{ABCC} 1$}

$\mathrm{ABCC} 1$, a potent efflux pump at the $\mathrm{BBB}$, is localized on both sides of the brain in capillary endothelial cells, astrocytes and pericytes [81, 150-152]. Several studies have demonstrated the involvement of ABCC1 in AD. In vivo studies showed that in APP/PS1 transgenic mice lacking $A B C C 1, A \beta_{40}$ and $A \beta_{42}$ levels were increased compared to those of ABCC1-positive controls [153]. The authors further found that thiethylperazine, an activator of $\mathrm{ABCC} 1$, could reduce the $\mathrm{A} \beta$ burden in APP/PS1 transgenic mice ${ }^{[153]}$. Similarly focused on ABCC1, Hofrichter et al provided the first specific evidence that St. John's wort could increase ABCC1 export activity in the $\mathrm{BBB}$ and reduce $\mathrm{A} \beta$ levels, thereby attenuating $\mathrm{A} \beta$ induced histopathology and alleviating memory impairments ${ }^{[154]}$. These results suggest that St. John's wort extracts might be a therapeutic drug for $\mathrm{AD}$ treatment, which necessitates further research.

\subsection{Influence of $A D$ progression on transporters}

A neglected issue in the literature has been the influence of $\mathrm{AD}$ progression on changes in brain transporters. The course of $\mathrm{AD}$ treatment is divided into four stages: predementia and early, moderate, and advanced stages, according to the progressive pattern of cognitive and functional impairment. Aging is the primary risk factor in $\mathrm{AD}$ progression and can change transporter expression [155]. For example, studies found an age-related decrease in P-gp expression in normal aging rats, which can exacerbate the intracerebral accumulation of $A \beta$. However, accumulated $A \beta$ can further downregulate P-gp expression [90]. Similarly, P-gp expression and activity are reduced in individuals with mild cognitive impairment and in $\mathrm{AD}$ patients, compared to normal individuals [156].

However, few researchers have focused on $A \beta$ transporter expression as related to different signs and symptoms of $\mathrm{AD}$, which might fortuitously be a new symptom marker in the early diagnosis of AD.

\section{Conclusions and future perspectives}

$\mathrm{ABC}$ transporters are involved in $\mathrm{AD}$ pathology directly or indirectly (Table 1). However, the molecular mechanisms have not been completely clarified and require further research. For instance, it is known that $\mathrm{ABCB} 1$ and $\mathrm{ABCG} 2$ are involved in $\mathrm{A} \beta$ clearance across the $B B B$. Unfortunately, their contribution ratio in the total $A \beta$ clearance in the brain is still unknown. A better understanding of the mechanisms by which genetic variability in $A B C$ and SLC transporters regulates $A \beta$ production and degradation is needed. Furthermore, understanding the roles of ABC and SLC transporters in tau pathology and other risk factors in $\mathrm{AD}$ may help further explain the disease-modulating effects of the transporters. Therefore, exhaustively clarifying $\mathrm{ABC}$ and SLC transporter functions and expression location in the human brain is important for the development and optimization of viable therapeutic strategies that target transporters to combat neurodegenerative diseases.

\section{Acknowledgements}

This research was supported by grants from the National Natural Science Foundation of China (No. 81803869, 81303248), University Nursing Program for Young Scholars with Creative Talents in Heilongjiang Province (UNPYSCT-2016116; UNPYSCT-2018032), Science and Technology Research Project of the Education Department of Heilongjiang Province (2017-KYYWF0697), and Item of Scientific Research Fund For Doctors of Qiqihar Medical University (QMSI2017B-10).

\section{Conflicts of Interest}

The authors declare no conflict of interest.

\section{References}

[1] Daneman R, Prat A (2015). The blood-brain barrier. Cold Spring Harb Perspect Biol, 7:a020412.

[2] Naessens DMP, de Vos J, VanBavel E, Bakker E (2018). Blood-brain and blood-cerebrospinal fluid barrier permeability in spontaneously hypertensive rats. Fluids Barriers CNS, 15:26.

[3] Engelhardt B, Sorokin L (2009). The blood-brain and the blood-cerebrospinal fluid barriers: function and dysfunction. Semin Immunopathol, 31:497-511.

[4] Pahnke J, Walker LC, Scheffler K, Krohn M (2009). Alzheimer's disease and blood-brain barrier functionWhy have anti-beta-amyloid therapies failed to prevent dementia progression? Neurosci Biobehav Rev, 33:1099-1108.

[5] Stieger B, Gao B (2015). Drug transporters in the central nervous system. Clin Pharmacokinet, 54:225242.

[6] Hartz AM, Miller DS, Bauer B (2010). Restoring blood-brain barrier P-glycoprotein reduces brain amyloid-beta in a mouse model of Alzheimer's disease. Mol Pharmacol, 77:715-723. 
[7] Sanchez-Covarrubias L, Slosky LM, Thompson BJ, Davis TP, Ronaldson PT (2014). Transporters at CNS barrier sites: obstacles or opportunities for drug delivery? Curr Pharm Des, 20:1422-1449.

[8] Luckenbach T, Fischer S, Sturm A (2014). Current advances on $\mathrm{ABC}$ drug transporters in fish. Comp Biochem Physiol C Toxicol Pharmacol, 165:28-52.

[9] Calatozzolo C, Gelati M, Ciusani E, Sciacca FL, Pollo B, Cajola L, et al. (2005). Expression of drug resistance proteins Pgp, MRP1, MRP3, MRP5 and GST-pi in human glioma. J Neurooncol, 74:113-121.

[10] Muller T (2018). ABCB1: is there a role in the drug treatment of Parkinson's disease? Expert Opin Drug Metab Toxicol, 14:127-129.

[11] Zenaro E, Piacentino G, Constantin G (2017). The blood-brain barrier in Alzheimer's disease. Neurobiol Dis, 107:41-56.

[12] Wong AD, Ye M, Levy AF, Rothstein JD, Bergles DE, Searson PC (2013). The blood-brain barrier: an engineering perspective. Front Neuroeng, 6:7.

[13] ElAli A, Theriault P, Rivest S (2014). The role of pericytes in neurovascular unit remodeling in brain disorders. Int J Mol Sci, 15:6453-6474.

[14] Shackleton B, Crawford F, Bachmeier C (2016). Inhibition of ADAM10 promotes the clearance of Abeta across the BBB by reducing LRP1 ectodomain shedding. Fluids Barriers CNS, 13:14.

[15] Pereira CD, Martins F, Wiltfang J, da Cruz ESOAB, Rebelo S (2018). ABC Transporters Are Key Players in Alzheimer's Disease. J Alzheimers Dis, 61:463-485.

[16] Banks WA (2009). Characteristics of compounds that cross the blood-brain barrier. BMC Neurol, 9 Suppl $1:$ S3.

[17] Mikitsh JL, Chacko AM (2014). Pathways for small molecule delivery to the central nervous system across the blood-brain barrier. Perspect Medicin Chem, 6:1124.

[18] Montagne A, Barnes SR, Sweeney MD, Halliday MR, Sagare AP, Zhao Z, et al. (2015). Blood-brain barrier breakdown in the aging human hippocampus. Neuron, 85:296-302.

[19] Zhao Z, Sagare AP, Ma Q, Halliday MR, Kong P, Kisler K, et al. (2015). Central role for PICALM in amyloid-beta blood-brain barrier transcytosis and clearance. Nat Neurosci, 18:978-987.

[20] Liao F, Yoon H, Kim J (2017). Apolipoprotein E metabolism and functions in brain and its role in Alzheimer's disease. Curr Opin Lipidol, 28:60-67.

[21] Bell RD, Winkler EA, Singh I, Sagare AP, Deane R, $\mathrm{Wu} \mathrm{Z}$, et al. (2012). Apolipoprotein E controls cerebrovascular integrity via cyclophilin A. Nature, 485:512-516.

[22] Niwa K, Kazama K, Younkin L, Younkin SG, Carlson GA, Iadecola C (2002). Cerebrovascular autoregulation is profoundly impaired in mice overexpressing amyloid precursor protein. Am J Physiol Heart Circ Physiol, 283:H315-323.

[23] Alata W, Ye Y, St-Amour I, Vandal M, Calon F (2015). Human apolipoprotein E varepsilon4 expression impairs cerebral vascularization and blood-brain barrier function in mice. $\mathrm{J}$ Cereb Blood Flow Metab, 35:86-94.

[24] Chan Y, Chen W, Wan W, Chen Y, Li Y, Zhang C (2018). Abeta1-42 oligomer induces alteration of tight junction scaffold proteins via RAGE-mediated autophagy in bEnd.3 cells. Exp Cell Res, 369:266-274.

[25] Stamatovic SM, Johnson AM, Keep RF, Andjelkovic AV (2016). Junctional proteins of the blood-brain barrier: New insights into function and dysfunction. Tissue Barriers, 4:e1154641.

[26] Furuse M (2010). Molecular basis of the core structure of tight junctions. Cold Spring Harb Perspect Biol, 2:a002907.

[27] Cerutti C, Ridley AJ (2017). Endothelial cell-cell adhesion and signaling. Exp Cell Res, 358:31-38.

[28] Nelson AR, Sweeney MD, Sagare AP, Zlokovic BV (2016). Neurovascular dysfunction and neurodegeneration in dementia and Alzheimer's disease. Biochim Biophys Acta, 1862:887-900.

[29] Marco S, Skaper SD (2006). Amyloid beta-peptide142 alters tight junction protein distribution and expression in brain microvessel endothelial cells. Neurosci Lett, 401:219-224.

[30] Lindmark T, Soderholm JD, Olaison G, Alvan G, Ocklind G, Artursson P (1997). Mechanism of absorption enhancement in humans after rectal administration of ampicillin in suppositories containing sodium caprate. Pharm Res, 14:930-935.

[31] Del Vecchio G, Tscheik C, Tenz K, Helms HC, Winkler L, Blasig R, et al. (2012). Sodium caprate transiently opens claudin-5-containing barriers at tight junctions of epithelial and endothelial cells. Mol Pharm, 9:2523-2533.

[32] Tachibana M, Yamazaki Y, Liu CC, Bu G, Kanekiyo T (2018). Pericyte implantation in the brain enhances cerebral blood flow and reduces amyloid-beta pathology in amyloid model mice. Exp Neurol, 300:13-21.

[33] Sengillo JD, Winkler EA, Walker CT, Sullivan JS, Johnson M, Zlokovic BV (2013). Deficiency in mural vascular cells coincides with blood-brain barrier disruption in Alzheimer's disease. Brain Pathol, 23:303-310.

[34] Halliday MR, Rege SV, Ma Q, Zhao Z, Miller CA, Winkler EA, et al. (2016). Accelerated pericyte degeneration and blood-brain barrier breakdown in apolipoprotein E4 carriers with Alzheimer's disease. J Cereb Blood Flow Metab, 36:216-227.

[35] Veszelka S, Toth AE, Walter FR, Datki Z, Mozes E, Fulop L, et al. (2013). Docosahexaenoic acid reduces amyloid-beta induced toxicity in cells of the neurovascular unit. J Alzheimers Dis, 36:487-501.

[36] Verbeek MM, de Waal RM, Schipper JJ, Van Nostrand WE (1997). Rapid degeneration of cultured human brain pericytes by amyloid beta protein. J Neurochem, 68:1135-1141.

[37] Kisler K, Nelson AR, Rege SV, Ramanathan A, Wang Y, Ahuja A, et al. (2017). Pericyte degeneration leads to neurovascular uncoupling and limits oxygen supply to brain. Nat Neurosci, 20:406-416. 
[38] Erdo F, Denes L, de Lange E (2017). Age-associated physiological and pathological changes at the bloodbrain barrier: A review. J Cereb Blood Flow Metab, 37:4-24.

[39] Ma Q, Zhao Z, Sagare AP, Wu Y, Wang M, Owens NC, et al. (2018). Blood-brain barrier-associated pericytes internalize and clear aggregated amyloid-beta42 by LRP1-dependent apolipoprotein E isoform-specific mechanism. Mol Neurodegener, 13:57.

[40] Maragakis NJ, Rothstein JD (2006). Mechanisms of Disease: astrocytes in neurodegenerative disease. Nat Clin Pract Neurol, 2:679-689.

[41] Vandenberg RJ, Ryan RM (2013). Mechanisms of glutamate transport. Physiol Rev, 93:1621-1657.

[42] Bjornsen LP, Hadera MG, Zhou Y, Danbolt NC, Sonnewald U (2014). The GLT-1 (EAAT2; slc1a2) glutamate transporter is essential for glutamate homeostasis in the neocortex of the mouse. J Neurochem, 128:641-649.

[43] Scott HA, Gebhardt FM, Mitrovic AD, Vandenberg RJ, Dodd PR (2011). Glutamate transporter variants reduce glutamate uptake in Alzheimer's disease. Neurobiol Aging, 32:553 e551-511.

[44] Kim K, Lee SG, Kegelman TP, Su ZZ, Das SK, Dash $\mathrm{R}$, et al. (2011). Role of excitatory amino acid transporter-2 (EAAT2) and glutamate in neurodegeneration: opportunities for developing novel therapeutics. J Cell Physiol, 226:2484-2493.

[45] Masliah E, Alford M, Mallory M, Rockenstein E, Moechars D, Van Leuven F (2000). Abnormal glutamate transport function in mutant amyloid precursor protein transgenic mice. Exp Neurol, 163:381-387.

[46] Schallier A, Smolders I, Van Dam D, Loyens E, De Deyn PP, Michotte A, et al. (2011). Region- and agespecific changes in glutamate transport in the AbetaPP23 mouse model for Alzheimer's disease. J Alzheimers Dis, 24:287-300.

[47] Jankowsky JL, Fadale DJ, Anderson J, Xu GM, Gonzales V, Jenkins NA, et al. (2004). Mutant presenilins specifically elevate the levels of the 42 residue beta-amyloid peptide in vivo: evidence for augmentation of a 42-specific gamma secretase. Hum Mol Genet, 13:159-170.

[48] Deng D, Yan N (2016). GLUT, SGLT, and SWEET: Structural and mechanistic investigations of the glucose transporters. Protein Sci, 25:546-558.

[49] Mergenthaler P, Lindauer U, Dienel GA, Meisel A (2013). Sugar for the brain: the role of glucose in physiological and pathological brain function. Trends Neurosci, 36:587-597.

[50] Shah K, Desilva S, Abbruscato T (2012). The role of glucose transporters in brain disease: diabetes and Alzheimer's Disease. Int J Mol Sci, 13:12629-12655.

[51] Jurcovicova J (2014). Glucose transport in brain effect of inflammation. Endocr Regul, 48:35-48.

[52] Stuart CA, Ross IR, Howell ME, McCurry MP, Wood TG, Ceci JD, et al. (2011). Brain glucose transporter (Glut3) haploinsufficiency does not impair mouse brain glucose uptake. Brain Res, 1384:15-22.
[53] Falkowska A, Gutowska I, Goschorska M, Nowacki P, Chlubek D, Baranowska-Bosiacka I (2015). Energy Metabolism of the Brain, Including the Cooperation between Astrocytes and Neurons, Especially in the Context of Glycogen Metabolism. Int J Mol Sci, 16:25959-25981.

[54] Mosconi L, Mistur R, Switalski R, Tsui WH, Glodzik $\mathrm{L}$, Li Y, et al. (2009). FDG-PET changes in brain glucose metabolism from normal cognition to pathologically verified Alzheimer's disease. Eur J Nucl Med Mol Imaging, 36:811-822.

[55] Hoyer S (2002). The brain insulin signal transduction system and sporadic (type II) Alzheimer disease: an update. J Neural Transm (Vienna), 109:341-360.

[56] Lyros E, Bakogiannis C, Liu Y, Fassbender K (2014). Molecular links between endothelial dysfunction and neurodegeneration in Alzheimer's disease. Curr Alzheimer Res, 11:18-26.

[57] Furst AJ, Lal RA (2011). Amyloid-beta and glucose metabolism in Alzheimer's disease. J Alzheimers Dis, 26 Suppl 3:105-116.

[58] Szablewski L (2017). Glucose Transporters in Brain: In Health and in Alzheimer's Disease. J Alzheimers Dis, 55:1307-1320.

[59] Simpson IA, Chundu KR, Davies-Hill T, Honer WG, Davies P (1994). Decreased concentrations of GLUT1 and GLUT3 glucose transporters in the brains of patients with Alzheimer's disease. Ann Neurol, 35:546-551.

[60] Winkler EA, Nishida Y, Sagare AP, Rege SV, Bell RD, Perlmutter D, et al. (2015). GLUT1 reductions exacerbate Alzheimer's disease vasculo-neuronal dysfunction and degeneration. Nat Neurosci, 18:521530.

[61] Mooradian AD, Chung HC, Shah GN (1997). GLUT1 expression in the cerebra of patients with Alzheimer's disease. Neurobiol Aging, 18:469-474.

[62] Kapogiannis D, Mattson MP (2011). Disrupted energy metabolism and neuronal circuit dysfunction in cognitive impairment and Alzheimer's disease. Lancet Neurol, 10:187-198.

[63] Kong W, Engel K, Wang J (2004). Mammalian nucleoside transporters. Curr Drug Metab, 5:63-84.

[64] Redzic ZB, Biringer J, Barnes K, Baldwin SA, AlSarraf H, Nicola PA, et al. (2005). Polarized distribution of nucleoside transporters in rat brain endothelial and choroid plexus epithelial cells. J Neurochem, 94:1420-1426.

[65] Hoshi Y, Uchida Y, Tachikawa M, Inoue T, Ohtsuki S, Terasaki T (2013). Quantitative atlas of blood-brain barrier transporters, receptors, and tight junction proteins in rats and common marmoset. J Pharm Sci, 102:3343-3355.

[66] Govindarajan R, Bakken AH, Hudkins KL, Lai Y, Casado FJ, Pastor-Anglada M, et al. (2007). In situ hybridization and immunolocalization of concentrative and equilibrative nucleoside transporters in the human intestine, liver, kidneys, and placenta. Am J Physiol Regul Integr Comp Physiol, 293:R1809-1822. 
[67] Lee CC, Chang CP, Lin CJ, Lai HL, Kao YH, Cheng SJ, et al. (2018). Adenosine Augmentation Evoked by an ENT1 Inhibitor Improves Memory Impairment and Neuronal Plasticity in the APP/PS1 Mouse Model of Alzheimer's Disease. Mol Neurobiol, 55:8936-8952.

[68] del Amo EM, Urtti A, Yliperttula M (2008). Pharmacokinetic role of L-type amino acid transporters LAT1 and LAT2. Eur J Pharm Sci, 35:161-174

[69] Dickens D, Webb SD, Antonyuk S, Giannoudis A, Owen A, Radisch S, et al. (2013). Transport of gabapentin by LAT1 (SLC7A5). Biochem Pharmacol, 85:1672-1683.

[70] Rossier G, Meier C, Bauch C, Summa V, Sordat B, Verrey F, et al. (1999). LAT2, a new basolateral 4F2hc/CD98-associated amino acid transporter of kidney and intestine. J Biol Chem, 274:34948-34954.

[71] Gynther M, Puris E, Peltokangas S, Auriola S, Kanninen KM, Koistinaho J, et al. (2018). Alzheimer's Disease Phenotype or Inflammatory Insult Does Not Alter Function of L-Type Amino Acid Transporter 1 in Mouse Blood-Brain Barrier and Primary Astrocytes. Pharm Res, 36:17.

[72] Hagenbuch B, Meier PJ (2003). The superfamily of organic anion transporting polypeptides. Biochim Biophys Acta, 1609:1-18.

[73] Brzica H, Abdullahi W, Ibbotson K, Ronaldson PT (2017). Role of Transporters in Central Nervous System Drug Delivery and Blood-Brain Barrier Protection: Relevance to Treatment of Stroke. J Cent Nerv Syst Dis, 9:1179573517693802.

[74] Abdullahi W, Davis TP, Ronaldson PT (2017). Functional Expression of P-glycoprotein and Organic Anion Transporting Polypeptides at the Blood-Brain Barrier: Understanding Transport Mechanisms for Improved CNS Drug Delivery? AAPS J, 19:931-939.

[75] Do TM, Bedussi B, Chasseigneaux S, Dodacki A, Yapo C, Chacun H, et al. (2013). Oatpla4 and an Lthyroxine-sensitive transporter mediate the mouse blood-brain barrier transport of amyloid-beta peptide. J Alzheimers Dis, 36:555-561.

[76] Yuasa H (2017). Foreword. Biological and Pharmaceutical Bulletin, 40:1129-1129.

[77] Wu X, Zhang J, Liu H, Mian Y, Liang B, Xie H, et al. (2015). Organic Anion Transporter 1 Deficiency Accelerates Learning and Memory Impairment in $\operatorname{tg} 2576$ Mice by Damaging Dendritic Spine Morphology and Activity. J Mol Neurosci, 56:730-738.

[78] Pan Y, Omori K, Ali I, Tachikawa M, Terasaki T, Brouwer KLR, et al. (2019). Increased Expression of Renal Drug Transporters in a Mouse Model of Familial Alzheimer's Disease. J Pharm Sci.

[79] Lin CJ, Tai Y, Huang MT, Tsai YF, Hsu HJ, Tzen KY, et al. (2010). Cellular localization of the organic cation transporters, OCT1 and OCT2, in brain microvessel endothelial cells and its implication for MPTP transport across the blood-brain barrier and MPTPinduced dopaminergic toxicity in rodents. J Neurochem, 114:717-727.

[80] Cordon-Cardo C, O'Brien JP, Casals D, Rittman-
Grauer L, Biedler JL, Melamed MR, et al. (1989). Multidrug-resistance gene (P-glycoprotein) is expressed by endothelial cells at blood-brain barrier sites. Proc Natl Acad Sci U S A, 86:695-698.

[81] Bernstein HG, Holzl G, Dobrowolny H, Hildebrandt J, Trubner K, Krohn M, et al. (2014). Vascular and extravascular distribution of the ATP-binding cassette transporters $\mathrm{ABCB} 1$ and $\mathrm{ABCC} 1$ in aged human brain and pituitary. Mech Ageing Dev, 141-142:12-21.

[82] Pahnke J, Langer O, Krohn M (2014). Alzheimer's and ABC transporters--new opportunities for diagnostics and treatment. Neurobiol Dis, $72 \mathrm{Pt} \mathrm{A:54-60.}$

[83] Potschka H, Fedrowitz M, Loscher W (2002). PGlycoprotein-mediated efflux of phenobarbital, lamotrigine, and felbamate at the blood-brain barrier: evidence from microdialysis experiments in rats. Neurosci Lett, 327:173-176.

[84] Lam FC, Liu R, Lu P, Shapiro AB, Renoir JM, Sharom FJ, et al. (2001). beta-Amyloid efflux mediated by pglycoprotein. J Neurochem, 76:1121-1128.

[85] van Assema DM, Lubberink M, Bauer M, van der Flier WM, Schuit RC, Windhorst AD, et al. (2012). Bloodbrain barrier P-glycoprotein function in Alzheimer's disease. Brain, 135:181-189.

[86] Cirrito JR, Deane R, Fagan AM, Spinner ML, Parsadanian M, Finn MB, et al. (2005). P-glycoprotein deficiency at the blood-brain barrier increases amyloid-beta deposition in an Alzheimer disease mouse model. J Clin Invest, 115:3285-3290.

[87] Bruckmann S, Brenn A, Grube M, Niedrig K, Holtfreter S, von Bohlen und Halbach O, et al. (2017). Lack of P-glycoprotein Results in Impairment of Removal of Beta-Amyloid and Increased Intraparenchymal Cerebral Amyloid Angiopathy after Active Immunization in a Transgenic Mouse Model of Alzheimer's Disease. Curr Alzheimer Res, 14:656-667. Vogelgesang S, Cascorbi I, Schroeder E, Pahnke J, Kroemer HK, Siegmund W, et al. (2002). Deposition of Alzheimer's beta-amyloid is inversely correlated with P-glycoprotein expression in the brains of elderly non-demented humans. Pharmacogenetics, 12:535541.

[89] Shubbar MH, Penny JI (2018). Effect of amyloid beta on ATP-binding cassette transporter expression and activity in porcine brain microvascular endothelial cells. Biochim Biophys Acta Gen Subj, 1862:23142322.

[90] Silverberg GD, Messier AA, Miller MC, Machan JT, Majmudar SS, Stopa EG, et al. (2010). Amyloid efflux transporter expression at the blood-brain barrier declines in normal aging. J Neuropathol Exp Neurol, 69:1034-1043.

[91] Alasmari F, Ashby CR, Jr., Hall FS, Sari Y, Tiwari AK (2018). Modulation of the ATP-Binding Cassette B1 Transporter by Neuro-Inflammatory Cytokines: Role in the Pathogenesis of Alzheimer's Disease. Front Pharmacol, 9:658.

[92] Sita G, Hrelia P, Tarozzi A, Morroni F (2017). Pglycoprotein (ABCB1) and Oxidative Stress: Focus on Alzheimer's Disease. Oxid Med Cell Longev, 
2017:7905486.

[93] Nazer B, Hong S, Selkoe DJ (2008). LRP promotes endocytosis and degradation, but not transcytosis, of the amyloid-beta peptide in a blood-brain barrier in vitro model. Neurobiol Dis, 30:94-102.

[94] Ito S, Ohtsuki S, Terasaki T (2006). Functional characterization of the brain-to-blood efflux clearance of human amyloid-beta peptide (1-40) across the rat blood-brain barrier. Neurosci Res, 56:246-252.

[95] Zhang C, Qin H, Zheng R, Wang Y, Yan T, Huan F, et al. (2018). A new approach for Alzheimer's disease treatment through P-gp regulation via ibuprofen. Pathol Res Pract, 214:1765-1771.

[96] Damar U, Gersner R, Johnstone JT, Schachter S, Rotenberg A (2016). Huperzine A as a neuroprotective and antiepileptic drug: a review of preclinical research. Expert Rev Neurother, 16:671-680.

[97] Li J, Yue M, Zhou D, Wang M, Zhang H (2017). Abcbla but not Abcg2 played a predominant role in limiting the brain distribution of Huperzine A in mice. Food Chem Toxicol, 107:68-73.

[98] Zhou D, Zhou W, Song JK, Feng ZY, Yang RY, Wu S, et al. (2016). DL0410, a novel dual cholinesterase inhibitor, protects mouse brains against Abeta-induced neuronal damage via the Akt/JNK signaling pathway. Acta Pharmacol Sin, 37:1401-1412.

[99] Yang RY, Zhao G, Wang DM, Pang XC, Wang SB, Fang JS, et al. (2015). DL0410 can reverse cognitive impairment, synaptic loss and reduce plaque load in APP/PS1 transgenic mice. Pharmacol Biochem Behav, 139:15-26.

[100] Lian W, Fang J, Xu L, Zhou W, Kang, Xiong W, et al. (2017). DL0410 Ameliorates Memory and Cognitive Impairments Induced by Scopolamine via Increasing Cholinergic Neurotransmission in Mice. Molecules, 22.

[101] Pang X, Wang L, Kang, Zhao Y, Wu S, Liu AL, et al. (2017). Effects of P-Glycoprotein on the Transport of DL0410, a Potential Multifunctional Anti-Alzheimer Agent. Molecules, 22.

[102] Mao Q, Unadkat JD (2005). Role of the breast cancer resistance protein (ABCG2) in drug transport. AAPS J, 7:E118-133.

[103] Do TM, Noel-Hudson MS, Ribes S, Besengez C, Smirnova M, Cisternino S, et al. (2012). ABCG2- and ABCG4-mediated efflux of amyloid-beta peptide 1-40 at the mouse blood-brain barrier. J Alzheimers Dis, 30:155-166.

[104] Shen S, Callaghan D, Juzwik C, Xiong H, Huang P, Zhang W (2010). ABCG2 reduces ROS-mediated toxicity and inflammation: a potential role in Alzheimer's disease. J Neurochem, 114:1590-1604.

[105] Xiong H, Callaghan D, Jones A, Bai J, Rasquinha I, Smith C, et al. (2009). ABCG2 is upregulated in Alzheimer's brain with cerebral amyloid angiopathy and may act as a gatekeeper at the blood-brain barrier for Abeta(1-40) peptides. J Neurosci, 29:5463-5475.

[106] Feher A, Juhasz A, Laszlo A, Pakaski M, Kalman J, Janka Z (2013). Association between the ABCG2 C421A polymorphism and Alzheimer's disease.
Neurosci Lett, 550:51-54.

[107] Zhou W, Hu X, Tam KY (2017). Systemic clearance and brain distribution of carbazole-based cyanine compounds as Alzheimer's disease drug candidates. Sci Rep, 7:16368.

[108] Cserepes J, Szentpetery Z, Seres L, Ozvegy-Laczka C, Langmann T, Schmitz G, et al. (2004). Functional expression and characterization of the human ABCG1 and $\mathrm{ABCG} 4$ proteins: indications for heterodimerization. Biochem Biophys Res Commun, 320:860-867.

[109] Tarr PT, Edwards PA (2008). ABCG1 and ABCG4 are coexpressed in neurons and astrocytes of the CNS and regulate cholesterol homeostasis through SREBP-2. J Lipid Res, 49:169-182.

[110] Dodacki A, Wortman M, Saubamea B, Chasseigneaux S, Nicolic S, Prince N, et al. (2017). Expression and function of Abcg4 in the mouse blood-brain barrier: role in restricting the brain entry of amyloid-beta peptide. Sci Rep, 7:13393.

[111] Sano O, Tsujita M, Shimizu Y, Kato R, Kobayashi A, Kioka N, et al. (2016). ABCG1 and ABCG4 Suppress gamma-Secretase Activity and Amyloid beta Production. PLoS One, 11:e0155400.

[112] Uehara Y, Yamada T, Baba Y, Miura S, Abe S, Kitajima K, et al. (2008). ATP-binding cassette transporter G4 is highly expressed in microglia in Alzheimer's brain. Brain Res, 1217:239-246.

[113] Boehm-Cagan A, Bar R, Liraz O, Bielicki JK, Johansson JO, Michaelson DM (2016). ABCA1 Agonist Reverses the ApoE4-Driven Cognitive and Brain Pathologies. J Alzheimers Dis, 54:1219-1233.

[114] Fernandez-Perez EJ, Sepulveda FJ, Peters C, Bascunan D, Riffo-Lepe NO, Gonzalez-Sanmiguel J, et al. (2018). Effect of Cholesterol on Membrane Fluidity and Association of Abeta Oligomers and Subsequent Neuronal Damage: A Double-Edged Sword. Front Aging Neurosci, 10:226.

[115] Akanuma S, Ohtsuki S, Doi Y, Tachikawa M, Ito S, Hori S, et al. (2008). ATP-binding cassette transporter A1 (ABCA1) deficiency does not attenuate the brainto-blood efflux transport of human amyloid-beta peptide (1-40) at the blood-brain barrier. Neurochem Int, 52:956-961.

[116] Fukumoto H, Deng A, Irizarry MC, Fitzgerald ML, Rebeck GW (2002). Induction of the cholesterol transporter $\mathrm{ABCA} 1$ in central nervous system cells by liver $\mathrm{X}$ receptor agonists increases secreted Abeta levels. J Biol Chem, 277:48508-48513.

[117] Kuntz M, Candela P, Saint-Pol J, Lamartiniere Y, Boucau MC, Sevin E, et al. (2015). Bexarotene Promotes Cholesterol Efflux and Restricts Apical-toBasolateral Transport of Amyloid-beta Peptides in an In Vitro Model of the Human Blood-Brain Barrier. J Alzheimers Dis, 48:849-862.

[118] Lee HJ, Ryu JM, Jung YH, Lee SJ, Kim JY, Lee SH, et al. (2016). High glucose upregulates BACE1mediated Abeta production through ROS-dependent HIF-1alpha and LXRalpha/ABCA1-regulated lipid raft reorganization in SK-N-MC cells. Sci Rep, 
$6: 36746$.

[119] Holtzman DM, Herz J, Bu G (2012). Apolipoprotein E and apolipoprotein $\mathrm{E}$ receptors: normal biology and roles in Alzheimer disease. Cold Spring Harb Perspect Med, 2:a006312.

[120] Wahrle SE, Jiang H, Parsadanian M, Hartman RE, Bales KR, Paul SM, et al. (2005). Deletion of Abca1 increases Abeta deposition in the PDAPP transgenic mouse model of Alzheimer disease. J Biol Chem, 280:43236-43242.

[121] Wahrle SE, Jiang H, Parsadanian M, Kim J, Li A, Knoten A, et al. (2008). Overexpression of ABCA1 reduces amyloid deposition in the PDAPP mouse model of Alzheimer disease. J Clin Invest, 118:671682.

[122] Wijesekara N, Kaur A, Westwell-Roper C, Nackiewicz D, Soukhatcheva G, Hayden MR, et al. (2016). ABCA1 deficiency and cellular cholesterol accumulation increases islet amyloidogenesis in mice. Diabetologia, 59:1242-1246.

[123] Akram A, Schmeidler J, Katsel P, Hof PR, Haroutunian V (2010). Increased expression of cholesterol transporter ABCA1 is highly correlated with severity of dementia in AD hippocampus. Brain Res, 1318:167-177.

[124] Li G, Kim C, Kim J, Yoon H, Zhou H, Kim J (2015). Common Pesticide, Dichlorodiphenyltrichloroethane (DDT), Increases Amyloid-beta Levels by Impairing the Function of ABCA1 and IDE: Implication for Alzheimer's Disease. J Alzheimers Dis, 46:109-122.

[125] Nordestgaard LT, Tybjaerg-Hansen A, Nordestgaard BG, Frikke-Schmidt R (2015). Loss-of-function mutation in ABCA1 and risk of Alzheimer's disease and cerebrovascular disease. Alzheimers Dement, 11:1430-1438.

[126] Chen Q, Liang B, Wang Z, Cheng X, Huang Y, Liu Y, et al. (2016). Influence of four polymorphisms in ABCA1 and PTGS2 genes on risk of Alzheimer's disease: a meta-analysis. Neurol Sci, 37:1209-1220.

[127] Lu J, Fu J, Zhong Y, Yang Q, Huang J, Li J, et al. (2018). Association between ABCA1 gene polymorphisms and the therapeutic response to donepezil therapy in Han Chinese patients with Alzheimer's disease. Brain Res Bull, 140:1-4.

[128] Ya L, Lu Z (2017). Differences in ABCA1 R219K Polymorphisms and Serum Indexes in Alzheimer and Parkinson Diseases in Northern China. Med Sci Monit, 23:4591-4600.

[129] Fan J, Zhao RQ, Parro C, Zhao W, Chou HY, Robert J, et al. (2018). Small molecule inducers of ABCA1 and apoE that act through indirect activation of the LXR pathway. J Lipid Res, 59:830-842.

[130] Kim WS, Guillemin GJ, Glaros EN, Lim CK, Garner B (2006). Quantitation of ATP-binding cassette subfamily-A transporter gene expression in primary human brain cells. Neuroreport, 17:891-896.

[131] Gosselet F, Candela P, Sevin E, Berezowski V, Cecchelli R, Fenart L (2009). Transcriptional profiles of receptors and transporters involved in brain cholesterol homeostasis at the blood-brain barrier: use of an in vitro model. Brain Res, 1249:34-42.

[132] Chan SL, Kim WS, Kwok JB, Hill AF, Cappai R, Rye $\mathrm{KA}$, et al. (2008). ATP-binding cassette transporter A7 regulates processing of amyloid precursor protein in vitro. J Neurochem, 106:793-804.

[133] Satoh K, Abe-Dohmae S, Yokoyama S, St GeorgeHyslop P, Fraser PE (2015). ATP-binding cassette transporter A7 (ABCA7) loss of function alters Alzheimer amyloid processing. J Biol Chem, 290:24152-24165.

[134] Sakae N, Liu CC, Shinohara M, Frisch-Daiello J, Ma L, Yamazaki Y, et al. (2016). ABCA7 Deficiency Accelerates Amyloid-beta Generation and Alzheimer's Neuronal Pathology. J Neurosci, 36:3848-3859.

[135] Kim WS, Li H, Ruberu K, Chan S, Elliott DA, Low $\mathrm{JK}$, et al. (2013). Deletion of Abca7 increases cerebral amyloid-beta accumulation in the J20 mouse model of Alzheimer's disease. J Neurosci, 33:4387-4394.

[136] Fu Y, Hsiao JH, Paxinos G, Halliday GM, Kim WS (2016). ABCA7 Mediates Phagocytic Clearance of Amyloid-beta in the Brain. J Alzheimers Dis, 54:569584.

[137] Lamartiniere Y, Boucau MC, Dehouck L, Krohn M, Pahnke J, Candela P, et al. (2018). ABCA7 Downregulation Modifies Cellular Cholesterol Homeostasis and Decreases Amyloid-beta Peptide Efflux in an in vitro Model of the Blood-Brain Barrier. J Alzheimers Dis, 64:1195-1211.

[138] May P, Pichler S, Hartl D, Bobbili DR, Mayhaus M, Spaniol C, et al. (2018). Rare ABCA7 variants in 2 German families with Alzheimer disease. Neurol Genet, 4:e224.

[139] Efthymiou AG, Goate AM (2017). Late onset Alzheimer's disease genetics implicates microglial pathways in disease risk. Mol Neurodegener, 12:43.

[140] Lambert JC, Heath S, Even G, Campion D, Sleegers K, Hiltunen M, et al. (2009). Genome-wide association study identifies variants at CLU and CR1 associated with Alzheimer's disease. Nat Genet, 41:1094-1099.

[141] Harold D, Abraham R, Hollingworth P, Sims R, Gerrish A, Hamshere ML, et al. (2009). Genome-wide association study identifies variants at CLU and PICALM associated with Alzheimer's disease. Nat Genet, 41:1088-1093.

[142] Zlokovic BV, Martel CL, Matsubara E, McComb JG, Zheng G, McCluskey RT, et al. (1996). Glycoprotein 330/megalin: probable role in receptor-mediated transport of apolipoprotein $\mathrm{J}$ alone and in a complex with Alzheimer disease amyloid beta at the bloodbrain and blood-cerebrospinal fluid barriers. Proc Natl Acad Sci U S A, 93:4229-4234.

[143] Bell RD, Sagare AP, Friedman AE, Bedi GS, Holtzman DM, Deane R, et al. (2007). Transport pathways for clearance of human Alzheimer's amyloid beta-peptide and apolipoproteins $\mathrm{E}$ and $\mathrm{J}$ in the mouse central nervous system. J Cereb Blood Flow Metab, 27:909-918.

[144] Zhao QF, Wan Y, Wang HF, Sun FR, Hao XK, Tan MS, et al. (2016). ABCA7 Genotypes Confer Alzheimer's 
Disease Risk by Modulating Amyloid-beta Pathology. J Alzheimers Dis, 52:693-703.

[145] Vasquez JB, Simpson JF, Harpole R, Estus S (2017). Alzheimer's Disease Genetics and ABCA7 Splicing. J Alzheimers Dis, 59:633-641.

[146] Liu LH, Xu J, Deng YL, Tang HD, Wang Y, Ren RJ, et al. (2014). A complex association of ABCA7 genotypes with sporadic Alzheimer disease in Chinese Han population. Alzheimer Dis Assoc Disord, 28:141144.

[147] Reitz C, Jun G, Naj A, Rajbhandary R, Vardarajan BN, Wang LS, et al. (2013). Variants in the ATP-binding cassette transporter (ABCA7), apolipoprotein E 4, and the risk of late-onset Alzheimer disease in African Americans. JAMA, 309:1483-1492.

[148] Logue MW, Schu M, Vardarajan BN, Buros J, Green RC, Go RC, et al. (2011). A comprehensive genetic association study of Alzheimer disease in African Americans. Arch Neurol, 68:1569-1579.

[149] Moreno-Grau S, Hernandez I, Heilmann-Heimbach S, Ruiz S, Rosende-Roca M, Mauleon A, et al. (2018). Genome-wide significant risk factors on chromosome 19 and the APOE locus. Oncotarget, 9:24590-24600.

[150] Wolf A, Bauer B, Hartz AM (2012). ABC Transporters and the Alzheimer's Disease Enigma. Front Psychiatry, 3:54.

[151] Gazzin S, Strazielle N, Schmitt C, Fevre-Montange M, Ostrow JD, Tiribelli C, et al. (2008). Differential expression of the multidrug resistance-related proteins $\mathrm{ABCb} 1$ and $\mathrm{ABCc} 1$ between blood-brain interfaces. J
Comp Neurol, 510:497-507.

[152] Ballerini P, Di Iorio P, Ciccarelli R, Nargi E, D'Alimonte I, Traversa U, et al. (2002). Glial cells express multiple ATP binding cassette proteins which are involved in ATP release. Neuroreport, 13:17891792.

[153] Krohn M, Lange C, Hofrichter J, Scheffler K, Stenzel J, Steffen J, et al. (2011). Cerebral amyloid-beta proteostasis is regulated by the membrane transport protein ABCC1 in mice. J Clin Invest, 121:3924-3931.

[154] Hofrichter J, Krohn M, Schumacher T, Lange C, Feistel B, Walbroel B, et al. (2013). Reduced Alzheimer's disease pathology by St. John's Wort treatment is independent of hyperforin and facilitated by $\mathrm{ABCC} 1$ and microglia activation in mice. Curr Alzheimer Res, 10:1057-1069.

[155] Guerreiro R, Bras J (2015). The age factor in Alzheimer's disease. Genome Med, 7:106.

[156] Deo AK, Borson S, Link JM, Domino K, Eary JF, Ke B, et al. (2014). Activity of P-Glycoprotein, a betaAmyloid Transporter at the Blood-Brain Barrier, Is Compromised in Patients with Mild Alzheimer Disease. J Nucl Med, 55:1106-1111. 